\title{
ホルムアルテヒドの重 合
}

(昭 和 37 年 12 月 28 日 受 理)

井本立也*・青谷 清. 史 ${ }^{*} \cdot$ 岩 崎 功**

$\alpha$-ポリオキシメチレンの熱分解によって得られるホルムフルデヒドを,トルエン溶液とし，ナトリウムメチラートを触 媒として， $-30 〜+20^{\circ} \mathrm{C}$ の箱用で重合を行なった。また一䒜高压重合も試みた。

重合は $-50^{\circ} \mathrm{C}$ 以下で起こらず，極限粘度 $1.0 \sim 3.3$ のボリマーが得られ，媒触量の少ない方が高分子量のものが得ら れ，末端基つセチル化によって極限粘度は增加し，熱安定性が著しくよくなった。熱安定性と極限粘度に相関関係が認め られ，極限粘度の高いほど，熱安定性が良いことが判った。また触媒量一極限粘度の関係から分子は系まり状であると考 えた。

\section{1 緒言}

ホルムアルデヒドは，極めて重合しやすい性質を持ち，求核試 薬, 親電子試薬のいずれによっても攻撃され，その重合はイオン 的に進行する1。年の重合体ポリオキシメチレンは，古くから多 くの人々によって研究され2), 特に Staudinger ${ }^{3)}$ は詳細な研究を 行なった。しかし高分子材料として，実用的価值はほとんぞ認め られるに至らなかった。しかるに非常に高い熱安定性をもち，か つ高分子量のホルムアルデヒド樹脂 (デルリン) ${ }^{4,9)}$ が発表されて 以来注目をあび，研究は多くの人によって行なわれ始め5)，放射 線重合融，高圧重合7) 等も行なわれたが，諭文の発表をみない。

そこで著者らはデルリンに近いポリホルムアルデヒドをつくる ベく、ナトリウムメチラートを用いて，重合を行なった。この触 媒はすで $C_{2}$ 以上のアルデヒドの重合に用いられ，またデルリ

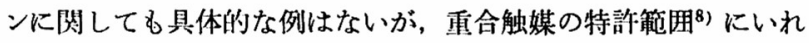
られている。本研究はこれらの詳練を確める目的をむって行なっ た。

重合物の熱安定性，極限粘度，融点を湘定し，熱安定性と極限

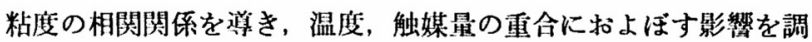
べまた構造は赤外吸収スペクトルによりデルリンと比較検討 した。高压重合は新しい方法を考察した。以下その結果を報告す る。

\section{2 実験}

\section{$2 \cdot 1$ 試 薬}

$\alpha$-ポリオキシメチレン；住友ベークライト慗のものを，五酸化 リン跑燥器に保存し, 使用直前に, 减圧, $185^{\circ} \mathrm{C}$ で, 約 $1 / 4$ 位分 解させて使用した。

ナトリウムメチラート；川上研究所製 95\% のものをそのまま

* 大阪市立大学工学部応用化学教室: 大阪市北区南厥町.

** 千代田化工建設株式会社：東京都千代田区丸の内.

1) J. E. Walker, J. Am. Chem. Soc. 55, 282 (1933).

2) J. E. Walker, "Formaldehyde" (1953).

3) H. Staudinger, Die Hochmolecularen Org. Verbindungen Kautschuk und Zellulose springen, Bellin (1932).

4) U. S. P. 2, 768, 994 (1956)；井本，樹脂加工 6, 229(1957); 高分子 389 (1957).

5) 井本, 太田, 岩佐, 高尾, 日化第 11 年会 (1959)；坦内, 福田, 日化第 12 年会 $(1960)$.

6) 岡村, 樹脂加工 9, 1 (1960)；化学 15，378 (1960).

7) 井本，“高王和合”高分子刊行会 (1959) p. 139.

8) Brit. P. 766,629 (1957)
使用した。

無水酢酸；市眅特級品を使用した。

無水酶酸ナトリウム；市眅品を焼いて使用した。

窒素ガス; 水酸化カリウム, ピロガロール溶液, 硫酸, 塩化カ ルシウム，五酸化リンの順に通して精製した。

トルエン；常法により精製,ナトリウム上で蒸留した。

\section{$2 \cdot 2$ 重 合}

重合は予備重合法9で行なった。図1のような装置を使用し， まず全系を真空乾燥後，精製窒素ガスを一端より通じ，系内が常

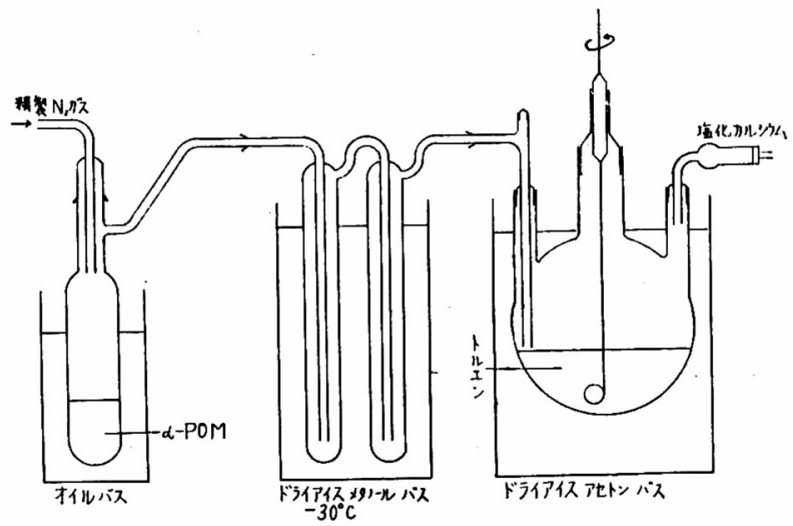

図 1 モノマー捕集装置

圧に戻ったとき, 分解管怙よび予備重合器に一定量の $\alpha$-ポリオ キシメチレンおよびトルェンをす早く入れる。その後トラップ， 予備重合器を所定の温度に冷却し, 分解管を $160 \sim 165^{\circ} \mathrm{C}$ に加熱 し， $\alpha$-ポリオキシメチレンを熱分解させて生ずるモノマーホルム アルデヒドを $-30^{\circ} \mathrm{C}$ の冷却トラップ 2 個に通し，不純物，水分 を除く。ころして得られる無水モノマーガスを， $300 \mathrm{ml}$ のトル エンを激しくかきまぜた $-80^{\circ} \mathrm{C}$ の予備重合器に捕集し, 一夜放 置する。

重合は完全に翰燥して窒素置換したフラスコに，触媒を少量の トルエンに分散させ， $-80^{\circ} \mathrm{C}$ に冷却守る。これに前日捕集した モノマー溶液を，外気にふれ奾よにサイホンで導入し，30 分 かきまぜ触媒が完全に分散してからパスを所定の温度にしたハ スに変え，重合を行なった。

高圧重合も同様の方法でモノマーを捕集し，図2の上5な方法 でモノマー溶液を, 触媒アンプルを入れた注射器に導入し，これ をオートクレーブに入れ, 常温, 加圧することにより注射器中の

9) 三枝, 化学 14，497 (1959). 


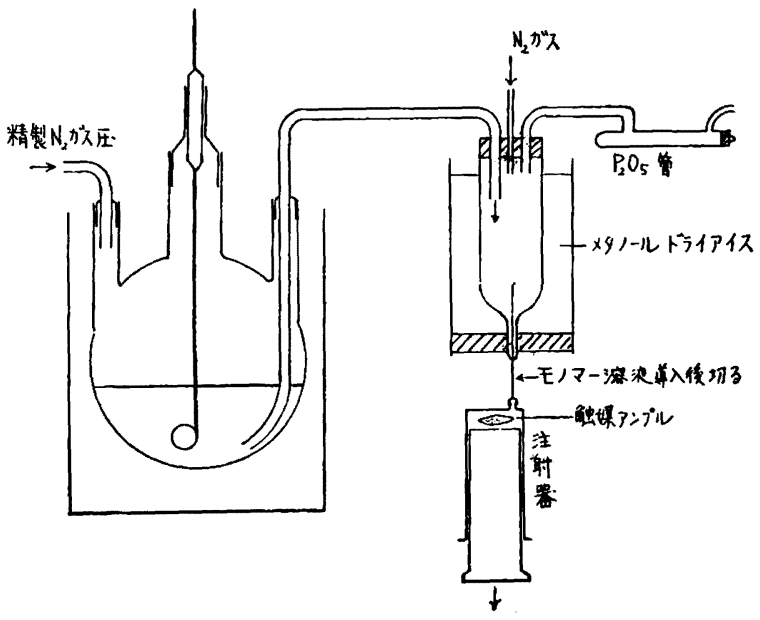

因 2 高圧重合に批けるモノマー導入装置

触媒アンプルを割り重合を行なった。

\section{$2 \cdot 3$ 重合物の処理}

得られた重合物は，口過により溶媒を除き，メタノール，水， アセトンで洗浄, 口過後, 五酸化リン乾嬠器で堿圧乾嬠した。

三, 三の重合物に対して, 無水酢酸ナトリウム, 無水酢酸によ り，末端基のアセチル化処理・゙行ない，処理前後の重合体を比 較検討した。

すべての重合物について，極限粘度，熱分解率，融点を湘定し た。極限粘度は， $2 \% \alpha$-ピネンを含む， $p$-クロルフェノール溶液 で，測定温度は $60 \pm 0.04^{\circ} \mathrm{C}$ である。

熱分解率の測定は，サリチル酸メチル蒸気浴 $\left(222^{\circ} \mathrm{C}\right)$ を用い約 $200 \mathrm{mg}$ の重合物を，アルミ䇴製の円筒中に入れ，タングステン バネにつなぎ，時間ごとの減量を記録し，分解速度が 1 次反応で あると仮定して, 未分解率, 対, 時間のプロットより分解速度定 数 $k_{222}(\% / \mathrm{min})^{4,10)}$ を求めた。

融点は常法により封管で測定した。

赤外吸収スペクトルは，プレスを用いて， $190^{\circ} \mathrm{C}, 300 \mathrm{~kg} / \mathrm{cm}^{2}$ で圧延してフィルムを作成しこれれよって測定した。

\section{3 实験結果および考察}

\section{$3 \cdot 1$ 重合の結果}

重合は, 反応時間は 3 時間, 温度，触媒量を変えて行なった。 その結果は表 1 に示す。

高圧法はモノマー溶液 $40 \mathrm{ml}$, 触媒 $2.2 \mathrm{mg}$ を注射器に入れて 行なったものである。

反応温度が $-50^{\circ} \mathrm{C}$ 以下では 1 冝夜かきませても重合は起こら なかった。重合開始とともに反応容器の温度は急激に上昇し，約 30 分でるとの温度に戻る。表 1 の左の温度はバス温度, 右は反 応のため上昇した最高温度である。

収率は最高 60\%で, 実験操作, 特にモノマー捕集の祭の窒素 の流速, 溶媒のかきませ，分解温度に大きく影繁して，触媒量，

温度との関係は得られなかった。

融点は，大体同じ様なもので $160 \sim 170^{\circ} \mathrm{C}$ の範囲で, $\alpha$-ポリオ キシメチンンの融点より若干低いようである。

高任法は，予備実験程度で結論を下せないが，新しい重合方法

10) C.E. Schweitzer, R. N. McDonald, J. Appl. Polymer Sci. 1, 158 (1959).
表 1 重合条件と重合物の性丝

\begin{tabular}{|c|c|c|c|c|c|}
\hline No. & $\begin{array}{l}\text { 重食温度 } \\
\left.{ }^{\circ} \mathbf{C}\right)\end{array}$ & $\begin{array}{l}\text { 重合時間 } 3 \mathrm{hr} \\
\text { (触 } \\
\text { (×10-3 mol) }\end{array}$ & $\begin{array}{l}\text { hr, }, \text { トルエン } \\
\text { 収 量 } \\
(\mathrm{g})\end{array}$ & $\begin{array}{c}300 \mathrm{ml} \\
\text { 融 } \\
\left({ }^{\circ} \mathrm{C}\right)\end{array}$ & $\begin{array}{c}k_{222} \\
(\% / \min )\end{array}$ \\
\hline 2 & $-30 \sim-26$ & 49.4 & 27.5 & $164 \sim 170$ & 15.0 \\
\hline 11 & $-30 \sim-26$ & 11.5 & 27.0 & $164 \sim 168$ & 12.8 \\
\hline 17 & $-33 \sim-28$ & 21.9 & 30.5 & $168 \sim 178$ & 7.7 \\
\hline 18 & $-32 \sim-29$ & 55.6 & 30.0 & $164 \sim 173$ & 6.2 \\
\hline 20 & $-30 \sim-23$ & 6.49 & 5.6 & $167 \sim 174$ & - \\
\hline 22 & $-30 \sim-26$ & 2. 30 & 2. 56 & $162 \sim 169$ & 12.3 \\
\hline 12 & $-22 \sim-17$ & 6.10 & 10.0 & $162 \sim 173$ & 7.8 \\
\hline 16 & $-24 \sim-18$ & 2.50 & 11.0 & $173 \sim 184$ & 7.9 \\
\hline 24 & $-20 \sim$ & 1.59 & 9.3 & $167 \sim 173$ & 6.2 \\
\hline 10 & $-16 \sim-2$ & 8. 52 & 26.5 & $165 \sim 174$ & 10.7 \\
\hline 19 & $-16 \sim-9$ & 1.85 & 2.5 & $167 \sim 173$ & 18.0 \\
\hline 9 & $-13 \sim-2$ & 12.6 & 26.0 & $162 \sim 167$ & 11.0 \\
\hline 21 & $-3 \sim+7$ & 10.9 & 23.4 & $165 \sim 174$ & 7.5 \\
\hline 8 & $+16 \sim$ & 32.8 & 21.0 & $160 \sim 167$ & 11.4 \\
\hline 23 & 高正法 室 & 温 $\left(20^{\circ} \mathrm{C}\right) \quad 1$ & $150 \mathrm{~kg} / \mathrm{cm}^{2}$ & $153 \sim 160$ & 11.9 \\
\hline 24 & " & & $650 "$ & $162 \sim 167$ & 11.6 \\
\hline 25 & " & & $350 "$ & $150 \sim 155$ & 11.8 \\
\hline
\end{tabular}

として可能性があるように思われた。

\section{$3 \cdot 2$ 末端基処理の結果}

アセチル化により末端基処理を行ない，処理前の重合体と，融 点熱分解率，極限粘度を比較した。その結果を表 2 に示す。

融点はほとんど同じであるが,融点範用が少し小さくなる。 $k_{223}$ は著しく減少し熱安定性は非常によくなる。極限粘度は大きくな る。

表 2 末端基処理の結果

重合物 $10 \mathrm{~g}$ 。無水酶酸 $150 \mathrm{ml}$ ，酶酸ナトリウム $100 \mathrm{mg}$ ， 反応時間 $30 \mathrm{~min}$, 反店温度 $134 \sim 139^{\circ} \mathrm{C}$

\begin{tabular}{|c|c|c|c|c|c|c|}
\hline \multirow[b]{2}{*}{ No. } & 处 & \multicolumn{2}{|l|}{ 理 前 } & 処 & 理 後 & \multirow[b]{2}{*}[\eta]{} \\
\hline & $\begin{array}{l}\left.\text { 融 }{ }^{\circ}{ }^{\circ} \mathbf{C}\right) \\
\end{array}$ & $\overbrace{(\% / \mathrm{min})}^{k_{222}}$ & {$[\eta]$} & 点 & $\begin{array}{c}k_{223} \\
(\% / \min )\end{array}$ & \\
\hline 10 & $165 \sim 174$ & 10.7 & 2.0 & $169 \sim 175$ & 0.4 & 3.0 \\
\hline 11 & $164 \sim 168$ & 12.8 & 1.3 & $169 \sim 172$ & 0.5 & 2.7 \\
\hline 18 & $164 \sim 173$ & 6.2 & 3.3 & $169 \sim 173$ & 0.2 & 4.0 \\
\hline 21 & $165 \sim 174$ & 7.5 & 1.8 & $168 \sim 173$ & 0.3 & 2.4 \\
\hline
\end{tabular}

\section{3 桓限粘度と熟安定性の関係}

表 1，2 の結果より，極限粘度と $k_{222}$ の相関関係を図 3 に示 した。これより両者の間に直線関係があるか、どうかは判らない が，極限粘度が上昇すると， $k_{222}$ は減少することは明らかである。 アセチル化処理したものに関しては，別の関係があるようである。

\section{4 触媒年の梗限粘度におよぼす影策}

表 1 より触媒量の極限粘度（分子量）に及ぼす影響を検討した。

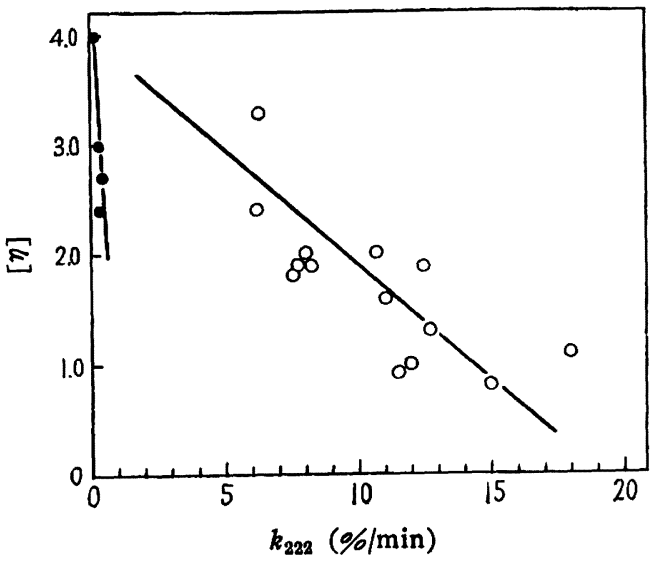

図 3 熱分解率と極限粘度の関係 


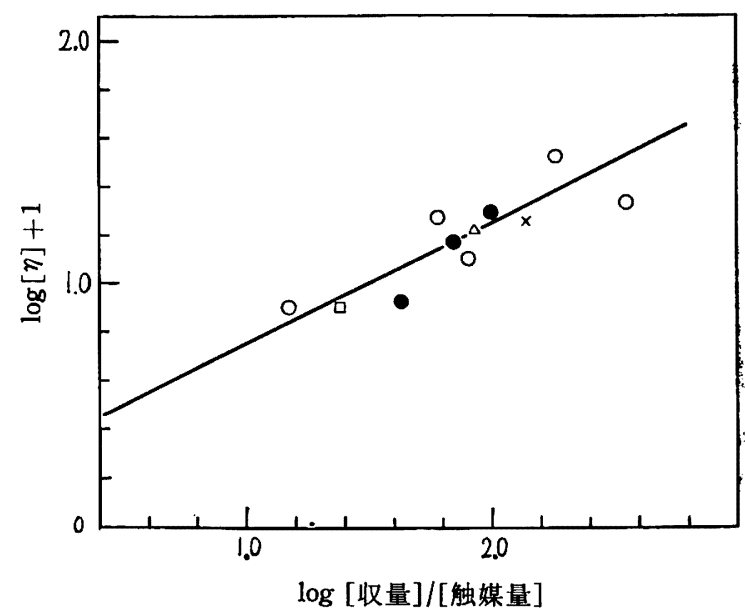

因 4 極限粘度之 [収量]/[触媒量] の関係 $O:-38^{\circ} \mathrm{C}, \times:-20^{\circ} \mathrm{C}, \bullet:-16 \sim-13^{\circ} \mathrm{C}, \Delta:-3^{\circ} \mathrm{C}, \square:$ 室温

この実験において，捕集されたモノマー量を正確に測定できない ので, 得られた重合体の収量をモノマー量と考える。一般にアニ オン重合において, $k$ [モノマー]/[触媒]=重合度 $(k=1$ または 2) の関係がある11)。また， $[\eta]=K P^{(12)}$ で表わされる。これら の関係から $k=1$ としたのが図 4 である。

これより極限粘度はあまり重合温度に関係のないことが判る。 また触媒量の減少とともに極限粘度は增加する。 $k=1,2$ の場合 の直線から $\alpha \fallingdotseq 0.6$ で分子は系まり状であると想像される。

11) J. E. Malvalay, C. G. Overberger, A. M. Schiller, Fortschr, Hochpolym-Forsch 3, 130 (1961).

12) 井本 稔, “合成高分子の化学” p. 52.

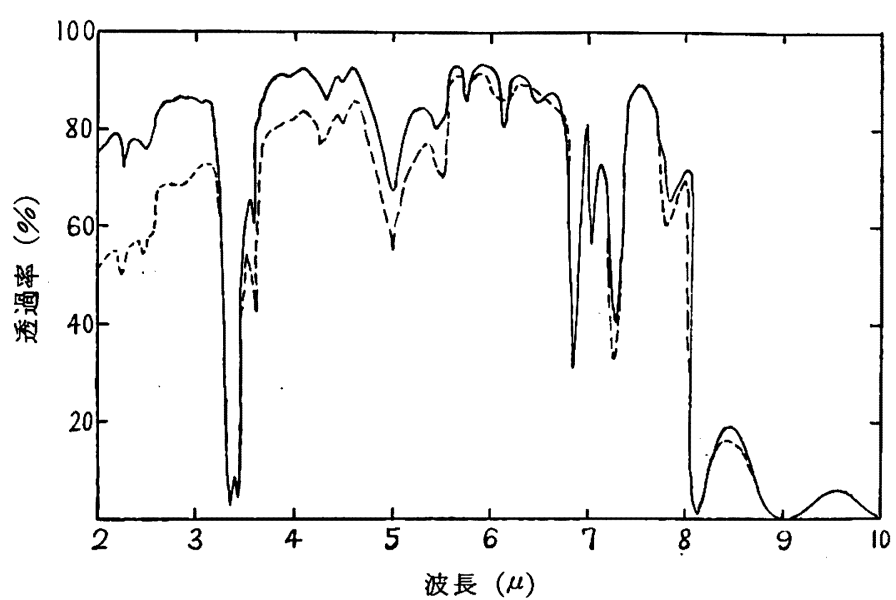

図 5 赤外吸収スペクトル

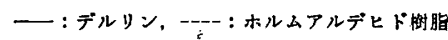

3.5 赤外吸収スペクトル

デルリンとの比較を図 5 に示す。フィルムの厚さが一定でな く、また少し厚いため細部の構造を検討することはできないが, デルリンと同様, ポリエーテル構造であると考えた。

以上のことから，この触媒によりデルリンに匹敵する重合体が できる可能性のあることが判った。 $\alpha, K$ の值は今後の研究で正 確な值を出す必要がある。高圧重合は本報では予備的実験にすぎ ないが, 高重合体を得る有力な方法と思われ, 今後研究する所存 である。

なお，本研究にあたり，資料を御提供下さいました住友べーク ライト株式会社に深く感謝致します。 